\title{
Development of an environmental risk characterization methodology for the Philadelphia Energy Risk Study
}

\author{
William C. Miller, P.E. \\ Penn State University, Great Valley Center \\ 30 East Swedesford Road, Malvern, Pennsylvania 19355 USA \\ Telephone: 215 685-1225; e-mail: 75051.230@compuserve.com
}

\begin{abstract}
Variations in the emission of arsenic compounds from large power plants in Philadelphia, Pennsylvania, are determined for the period 1950 through 1990. Estimation of the annual average concentration of the airborne arsenic component of particulate matter is presented. A unit risk assessment is used to estimate the historical variation in public health risk. The results of the risk assessment are presented graphically in a contour map format using a "risk power" parameter.
\end{abstract}

\section{Keywords}

Risk characterization, air pollution, power plants, Philadelphia, trace metals, visualization

\section{INTRODUCTION}

The primary focus of this report concerns the changes in particulate emissions from fossil fuel combustion sources in the electric power generation sector that have occurred through fuel switching in Philadelphia, Pennsylvania (Wainwright). The major fuel switching action to be considered is coal to oil. The effect of this fuel switching action is the variation in the emission of toxic air contaminants.

The primary toxic particulate air contaminants emitted from coal-fired electric utility boilers include the trace metal species arsenic, beryllium, cadmium, chromium, lead, mercury, and nickel (EPA 1991). These seven minerals may also present in fuel oil and are absent from natural gas. The relationship between the type and amount of fuel used and the exposure of individuals to these emissions is explored through public health risk 
characterization. This relationship can then be analyzed to determine its utility as a basis for linking environmental policy, energy policy, and efforts to understand and resolve the problem of trace metal emissions into the atmosphere (Kowalcyzk et al.).

This linkage would become a useful tool for use by policymakers in formulating emission control strategies. The marketing of various strategy options would be enhanced by the availability of a mechanism to allow the individual citizen to understand the benefit of reduced health risk derived from proposed strategies. This "personalization" process will likely increase the acceptance of otherwise difficult emission reduction measures that, until now, would have been viewed in a detached or impersonal sense.

\section{CURRENT METHODOLOGY}

An essential aspect of this investigation is the development of an improved method for linking the results derived from estimating toxic air contaminant emissions from large electric utility boilers and characterization the public health risk of exposure to the toxic air contaminants. Fortunately the various individual analytical components required to support this investigation are currently available as described below.

The U.S. Environmental Protection Agency (EPA) has developed a reference database for emission factors for toxic air contaminants as part of the Aerometric Information and Retrieval System - Air Facilities Subsystem (AIRS-AFS). This data is available through the "PM Profile Speciation Report" for each common type of utility boiler. A typical retrieval from this system can provide emission data for individual metal species and other toxic particulate contaminants. General emission estimates are also available in the Compilation of Air Pollutant Emission Factors, published by the EPA (EPA 1991).

The Electric Power Research Institute has developed the Air Emissions Risk Assessment Model (AERAM-2) which assesses the public health risk associated with the emission of air contaminants from utility boilers (EPRI 1985, EPRI 1988). The risk is determined through a four-step process:

1. Characterization of the air contaminants emitted from the power plant.

2. Calculation of ambient pollutant concentrations through air dispersion modeling.

3. Estimation of the exposure of the receptor population to the air contaminants.

4. Public health risk assessment and characterization based on the exposure estimates.

The AERAM-2 emission characterization module contains several options that allow for automatic calculation of emission estimates or the use of actual data such as that provided by the Speciation Report. The Speciation Report data can be further refined where actual fuel chemical analysis is available. The resulting air contaminant emission data are analyzed with meteorological data and receptor location data in the multi-source air dispersion model 
ISCLT-2 developed by EPA (EPA 1992). The model results are combined with population data to provide an estimate of the dose to each individual. The dose data and health effects data for each contaminant are then analyzed by dose-response models or analyzed through a unit risk factor analysis.

This general approach is satisfactory for investigating the potential effects of a new source or fuel type change (a static situation). It is limited, however, in the study of long-term or historical health effects associated with exposure to airborne toxic trace metal compounds at differing times when using the commonly accepted unit risk analysis method. The key problem lies in the dynamic nature of the population (receptor groups) under study. Population is an uncontrolled variable subject to the normal movement of individuals to and from the study area during a multi-period or long-term study. The establishment of a link between exposure and health effect is further confounded by genetics and the variety of exposures that an individual experiences through occupation and personal habits (smoking). This natural phenomenon weakens the usefulness of the population exposure assessment in the AERAM-2 model under these dynamic conditions.

This weakness arises from the nature of the unit risk analytical procedure. Unit risk refers to the specific epidemiological concept defined as the probability of one person developing cancer or some other disease during a seventy year (life span) exposure to one microgram per cubic meter of the contaminant. For example, the unit risk for arsenic is $0.0043\left[\mathrm{ug} / \mathrm{m}^{3}\right]^{-1}$ (EPA 1995). The application of the unit risk factor is described in Equation 1.

Risk $=[$ unit risk factor $] \times[$ contaminant concentration $] \times[$ population $]$

The numerical values derived from this type of analysis are treated as statistical probabilities. Values less than $10^{-6}$ are common and are usually accepted as meaning "no effect". Larger values indicate that some level of concern or response is warranted depending on the magnitude and type of health effect (Naugle \& Pierson).

This report proposes the modification of Equation 1 by eliminating the population term and converting the resulting exposure risk factor to a "risk power" value, $p R$, as shown in Equations 2 and 3.

Exposure Risk $=[$ unit risk factor $] \times[$ contaminant concentration $]$

$p R=-\log ($ Exposure Risk)

This $p R$ value permits comparison of potential public health risk at a specific location for multiple time periods without the confounding effect of population dynamics. The logarithmic scale simplifies the display of the large range of data values which may be involved in the plotting of the exposure risk data on a map. 
A contour map developed from this type of data can quite easily show the areas of interest by simply designating an action level or "breakpoint" value and formatting the contour line appropriately. For the purposes of the case study described below two breakpoints are defined. Locations where the $p R$ value is greater than 6 (equivalent to values less than $10^{-6}$ ) no values are displayed since there would be no effect. Values between 6 and 5 would be displayed, but would be considered a transition region only. Values of 5 or less would be displayed and highlighted by a contour line with a unique font, color, or format. In the regulatory philosophy of many states and the EPA a value of 5 would be considered as the threshold "action level."

\section{CASE STUDY DESIGN}

The development and demonstration of the proposed methodology is shown through a case study of the history of fossil-fueled electric power generation in the City of Philadelphia during the final year of each decade for the period 1950-1990. Four questions are considered in this case study:

1. What is the estimated risk to public health from the toxic air contaminants (limited to trace metals) emitted from the power plants in the City during this period? The case study and methodology uses arsenic as the example of a trace metal.

2. What are the long-term trends in emissions and air quality due to the operation of electric power generating facilities in Philadelphia.

3. What long-term benefit does fuel-switching provide in a strategy to reduce public exposure to toxic air contaminants emitted from electric power generating facilities?

4. What general environmental and energy policy implications can be derived from the specific results of the case study? These implications may range from local city planning issues to international development issues.

The case study examines the effect of arsenic emissions from the four large electric power generating stations operated by the Philadelphia Electric Company (PECo) within the city limits and the two large PECo stations located in the nearby suburbs. The majority of these generating stations have switched from coal to oil during the study period (Feng).

Exposed population data and corresponding risk estimates are organized on a one kilometer square grid system using census tract based population data. Census data and utility operating represent the years 1950, 1960, 1970, 1980, and 1990 (CPC). Supporting data (meteorology, toxicology, etc.) and analytical software (AERAM-2, mapping, statistical analysis, etc.) are available from public sources. 


\section{ANALYSIS}

Evaluation of the case study and methodology proposed above is presented here in order to demonstrate the feasibility of the proposal. This effort includes the development of the required information resources including power plant physical characteristics, fuel use, emission estimates, geographical and population data sets.

\subsection{Geographical Data}

The air quality dispersion model used in this investigation requires the establishment of a three-dimensional reference grid system to relate the sources (power plants) and receptors (population) in the estimation of ambient atmospheric concentrations of the subject pollutant. This grid system was created on a scale using one kilometer squares as a representative receptor. The standard Universal Transverse Mercator (UTM) coordinate system is the basis for the grid. The ISCLT-2 dispersion model uses this system as its default horizontal component.

The location of the six point sources for the model and the city boundaries were reduced to the UTM system and define the limits of the model input and output data. This relationship is shown in Figure 1. Source coordinates, city boundaries, and elevations were determined from U.S. Geological Survey topographic maps. A representative elevation in meters was estimated at the center of each grid square. The power plant base elevation was estimated in the same manner. The actual study area (receptor location grid) consists of five hundred seventeen squares covering the entire Philadelphia city limits as shown in Figure 2. The three-dimensional coordinates at the center of each square (UTM east, UTM north, and elevation) locates each receptor for modeling purposes.

The relative location of each major source with respect to the "Center" of the study area is as follows:

$\begin{array}{lr}\text { Delaware Station } & 2.6 \text { miles }(4.3 \mathrm{~km}) \text { south } \\ \text { Richmond Station } & 2.7 \text { miles }(4.4 \mathrm{~km}) \text { southeast } \\ \text { Schuylkill Station } & 5.7 \text { miles }(9.3 \mathrm{~km}) \text { southwest } \\ \text { Southwark Station } & 6.3 \text { miles }(10.3 \mathrm{~km}) \text { south-southwest } \\ \text { Eddystone Station } & 14.7 \text { miles }(24.1 \mathrm{~km}) \text { southeast } \\ \text { Cromby Station } & 24.3 \text { miles }(39.8 \mathrm{~km}) \text { northwest }\end{array}$

\subsection{Population Data}

The receptor grid system developed above was used to convert census data for the five study years into a population value for each grid square. Census Tract maps for each year were overlain with the UTM grid. The proportion (area) of each census tract within the grid square was estimated. The resulting fractions of each census tract were summed into a population estimate for each grid square. 


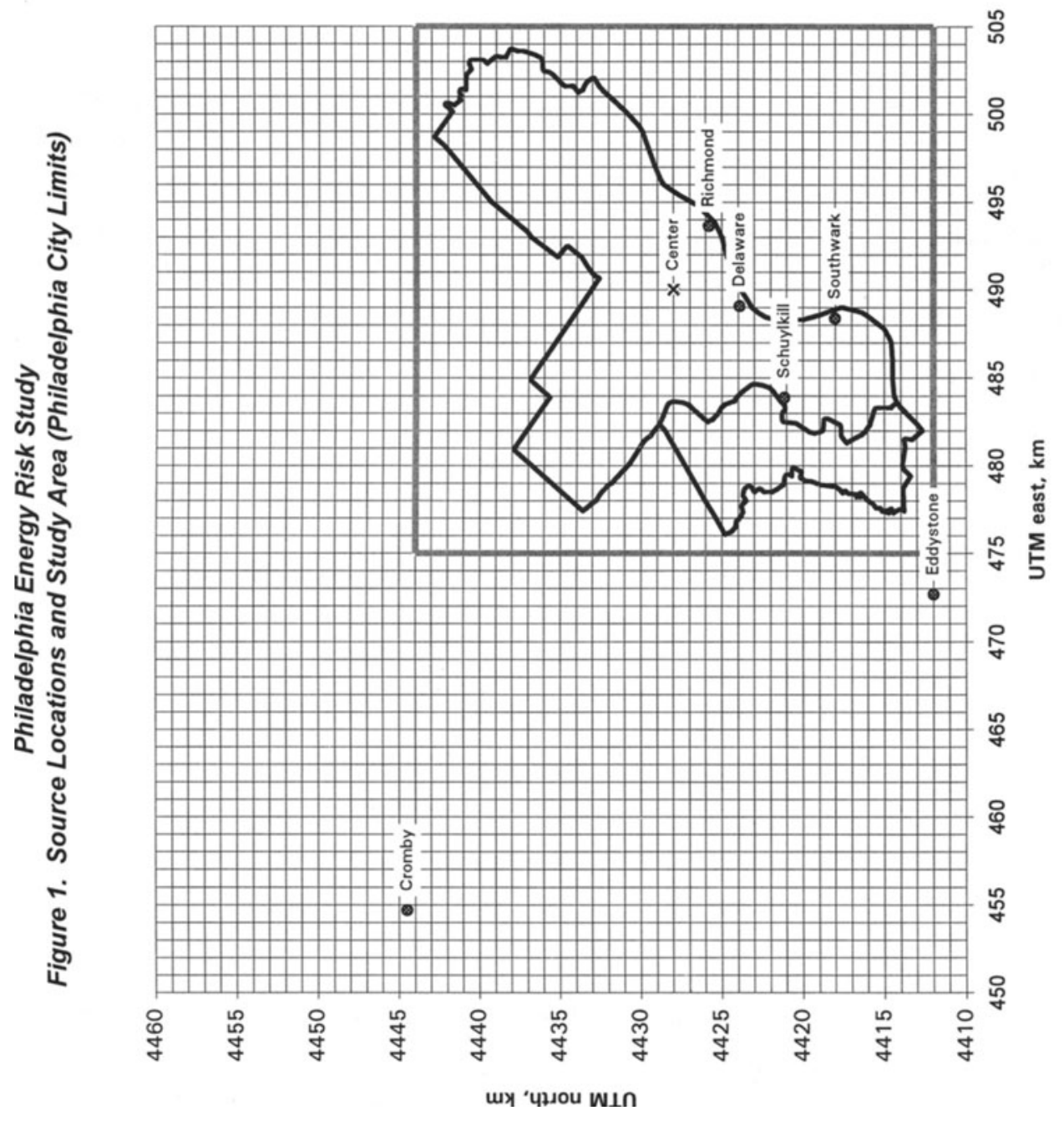


Figure 2. Air Dispersion Model Receptor Grid (numbers) and Planning Analysis Sections (letters)

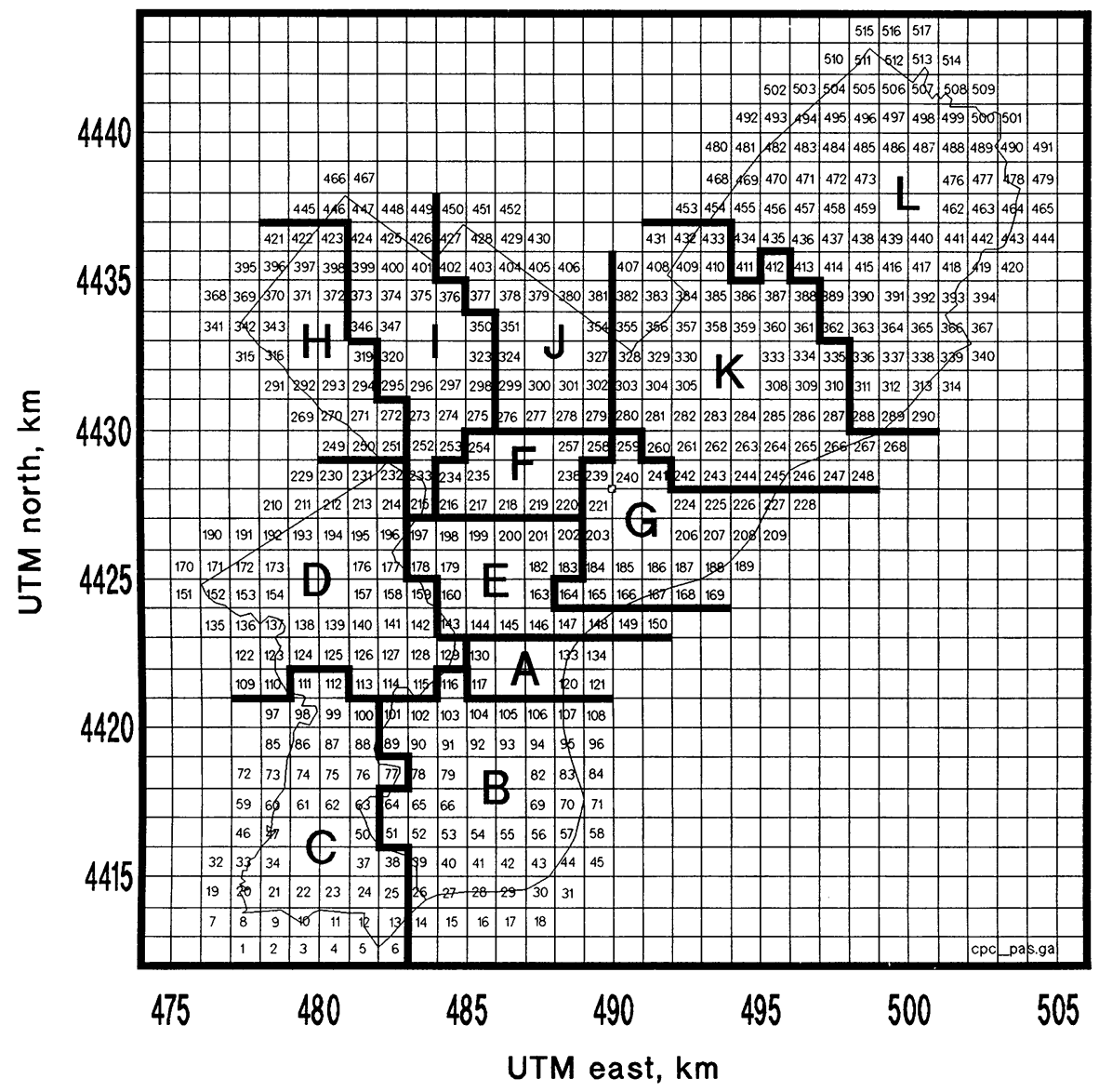


The Philadelphia City Planning Commission (CPC) has grouped census tracts into twelve Planning Analysis Sections for larger scale analytical purposes. A summary of the population variation over the study period is illustrated in Table 1 and Figure 3. This aggregate receptor population grid may be useful in analyzing the results of the risk assessment on a "neighborhood" basis.

\subsection{Source Data}

The electric power generating stations chosen for this case study were selected on the basis of size, location, tenure, and experience with fuel switching. The six stations included have a rated output in excess of $100 \mathrm{MW}$ each. Smaller stations in the city not included are Willow, Edison, and a portion of the Schuylkill Station which operated seasonally to provide central steam and the small suburban stations at Chester and Barbadoes (Norristown). Monthly reports of fuel type, quantity used, and sulfur content are available from the U.S. Department of Energy and the former Federal Power Commission on FPC Form 67 (or similar) for each station operating under the management of a public utility (FPC 1950, FPC 1970, DOE 1990). This information is summarized in Table 2.

Physical data describing boiler operating parameters and stack size was obtained from the 1971 U.S. EPA emission inventory project for the City of Philadelphia and a 1973 report to the Philadelphia City Council concerning the effect of various sulfur-in-fuel values being considered for the Philadelphia Air Management Code (AMS $a$, AMS $b$ ).

\subsection{Emission Estimates}

Fuel use information for each station was disaggregated for each stack (boiler) on a proportional basis using boiler rated capacity. The U.S. EPA Compilation of Emission Factors (AP-42) was used to determine emission estimates for Particulate Matter (PM), Sulfur Dioxide $\left(\mathrm{SO}_{2}\right)$, Carbon Monoxide (CO), Carbon Dioxide $\left(\mathrm{CO}_{2}\right)$, several organic compounds, and the toxic metals targeted for this investigation.

\subsection{Dispersion Model Data}

The first two modules of the AERAM-2 system described above (source characterization and dispersion modeling) were replaced by the direct use of the U.S. EPA Industrial Complex Source-Long Term (ISCLT-2) model. The model provides receptor concentration results in a file format compatible with the AERAM-2 population exposure assessment and risk characterization modules.

Input to the ISCLT-2 model consists of three types of data. The point source physical data and emission data developed above; summary meteorological data in standard Stability Array summary format (STAR data) representing the long-term weather conditions controlling the 


\section{Philadelphia Energy Risk Study}

Table 1. Philadelphia City Planning Commission -- Planning Analysis Section Summary

\begin{tabular}{|c|c|c|c|c|c|c|}
\hline \multirow[b]{2}{*}{ PAS } & \multirow[b]{2}{*}{ Section Name } & \multicolumn{5}{|c|}{ Annual Population } \\
\hline & & 1950 & 1960 & 1970 & 1980 & 1990 \\
\hline$\overline{\mathbf{A}}$ & Center City & 62,373 & 44,825 & 44,782 & 41,897 & 44,267 \\
\hline B & South Philadelphia & 297,890 & 247,863 & 225,006 & 185,260 & 168,105 \\
\hline C & Southwest Philadelphia & 113,316 & 103,523 & 100,248 & 90,049 & 85,138 \\
\hline D & West Philadelphia & 333,749 & 305,948 & 279,538 & 235,922 & 222,645 \\
\hline $\mathbf{E}$ & Lower North Philadelphia & 368,342 & 315,351 & 243,831 & 176,165 & 152,186 \\
\hline $\mathbf{F}$ & Upper North Philadelphia & 151,965 & 139,739 & 133,990 & 114,610 & 105,689 \\
\hline G & Bridesburg/Kensington/Richmond & 157,220 & 141,770 & 126,018 & 105,004 & 99,387 \\
\hline H & Roxborough/Manayunk & 39,035 & 41,362 & 50,097 & 45,896 & 43,042 \\
\hline $\mathbf{I}$ & Germantown/Chestnut Hill & 101,656 & 102,892 & 103,452 & 89,827 & 83,709 \\
\hline$J$ & Olney/Oak Lane & 175,821 & 189,551 & 190,126 & 180,652 & 172,771 \\
\hline $\mathbf{K}$ & Near Northeast Philadelphia & 237,283 & 291,793 & 289,284 & 253,468 & 242,088 \\
\hline $\mathbf{L}$ & Far Northeast Philadelphia & 29,955 & 74,213 & 161,527 & 169,462 & 166,499 \\
\hline & Tot & $\overline{068,605}$ & 998,831 & $, 947,899$ & $1,688,210$ & $, 585,523$ \\
\hline
\end{tabular}

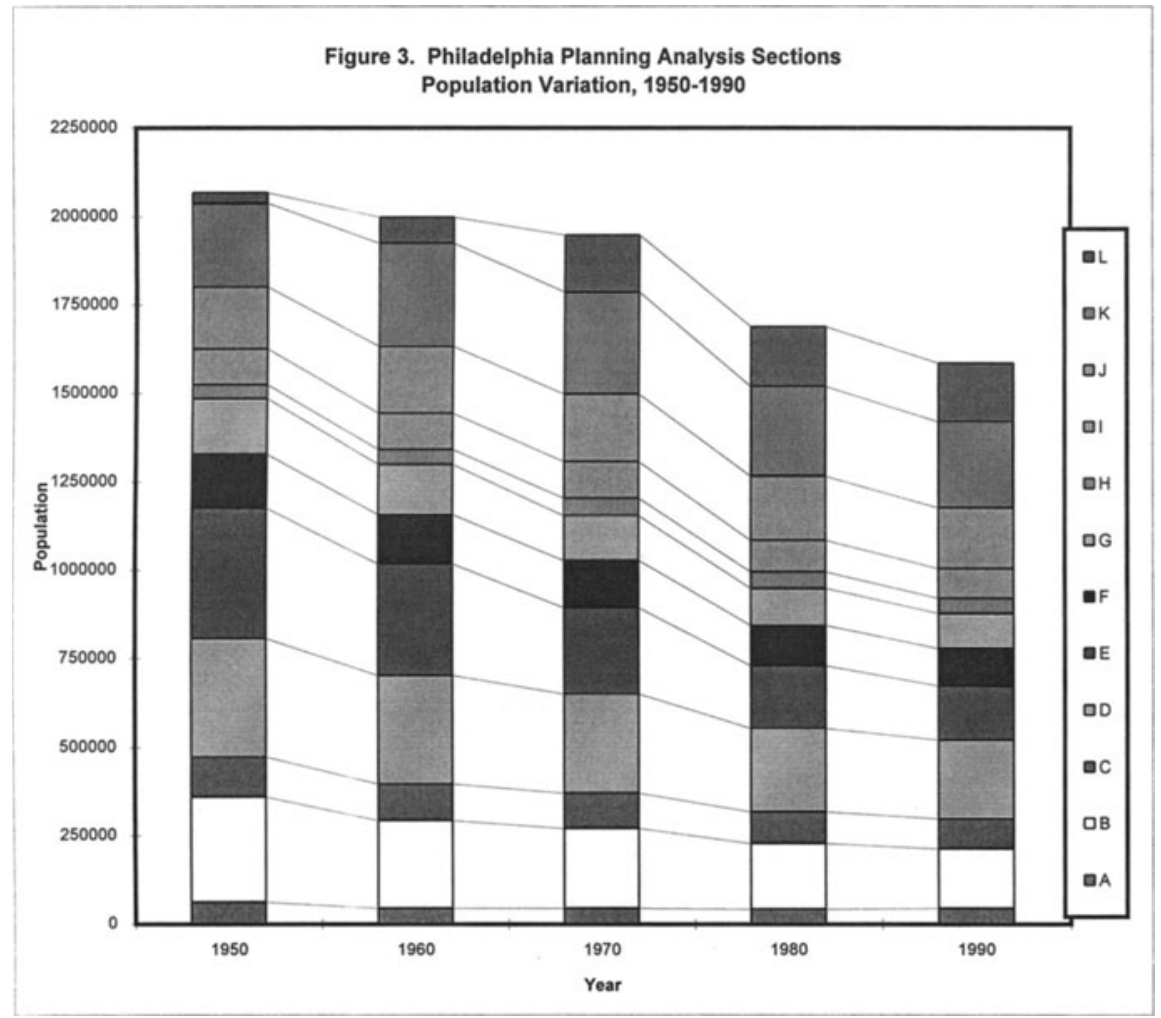


Philadelphia Energy Risk Study

Table 2. Annual Aggregate Fuel Usage by Station

\begin{tabular}{|c|c|c|c|c|c|c|c|c|c|c|}
\hline Station & 1950 & 1950 & 1960 & 1960 & 1970 & 1970 & 1980 & 1980 & 1990 & 1990 \\
\hline & & & & & & & & & & \\
\hline & & & & \multicolumn{5}{|c|}{ Natural Gas Fuel Use (1000 cubic feet/yr) } & & \\
\hline & & & & & & & & & & \\
\hline \multicolumn{11}{|l|}{ Cromby } \\
\hline \multirow[t]{2}{*}{ Eddystone } & & & & & & & & & $1 / 6618.6$ & $100 \%$ \% \\
\hline & & & & & & & & & & \\
\hline \multicolumn{11}{|l|}{ Delaware } \\
\hline \multicolumn{11}{|l|}{ Richmond } \\
\hline \multicolumn{11}{|l|}{ Southwark } \\
\hline \multicolumn{11}{|l|}{ Schuylkill } \\
\hline & & & & & & & & & & \\
\hline \multirow[t]{5}{*}{ Annual Total } & 0 & $0.0 \%$ & 0 & $0.0 \%$ & 0 & $0.0 \%$ & 0 & & 1761933 & $100.0 \%$ \\
\hline & & & & & & & & & & \\
\hline & & & & & & & & & & \\
\hline & & & & \multicolumn{4}{|c|}{ \#6 Oil Fuel Use (1000 U.S. gallons/yr) } & & & \\
\hline & & & & & & & & & & \\
\hline Cromby & & & & & 26763 & $13.0 \%$ & 59206 & $15.6 \%$ & 17865 & $14.1 \%$ \\
\hline \multirow[t]{2}{*}{ Eddystone } & & & & & & & 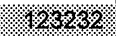 & $32.5 \%$ & 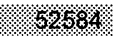 & $1 \%$ \\
\hline & & & & & & & & & & \\
\hline Delaware & & & 496 & $1.4 \%$ & 36047 & $17.5 \%$ & 44251 & $11.7 \%$ & 30686 & $24.1 \%$ \\
\hline Richmond & & & 3361 & $9.5 \%$ & $386 \%$ & $\% \%$ & 17518 & $4.6 \%$ & & \\
\hline Southwark & 5745 & $29.5 \%$ & 66 & $0.2 \%$ & 44842 & $21.8 \%$ & 32937 & $8.7 \%$ & & \\
\hline Schuylkill & $13 \%$ & $70.5 \%$ & $1 / 1 / 45$ & $80 \%$ & 47594 & $23.1 \%$ & 102411 & $27.0 \%$ & 25946 & $20.4 \%$ \\
\hline \multirow[t]{5}{*}{ Annual Total } & 19473 & $100.0 \%$ & 35376 & $100.0 \%$ & 206120 & $100.0 \%$ & 379554 & $100.0 \%$ & 127081 & $100.0 \%$ \\
\hline & & & & & & & & & & \\
\hline & & & & & & & & & & \\
\hline & & & & \multicolumn{3}{|c|}{ Coal Fuel Use (tons/yr) } & & & & \\
\hline & & & & & & & & & & \\
\hline Cromby & & & $9066 \%$ & $26 \%$ & 320385 & $18.0 \%$ & 287880 & $26.5 \%$ & 121282 & $16.6 \%$ \\
\hline \multirow[t]{2}{*}{ Eddystone } & & & 595016 & $17.2 \%$ & $1 \% 96 \%$ & 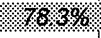 & 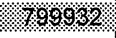 & $6 \%$ & $6186 \%$ & $88 \%$ \\
\hline & & & . & & & & & & & \\
\hline Delaware & 252640 & $19.2 \%$ & 708649 & $20.5 \%$ & & & & & & \\
\hline Richmond & 149217 & $11.3 \%$ & 667230 & $19.3 \%$ & 66680 & $3.7 \%$ & & & & \\
\hline Southwark & 6.1066 & $69.4 \%$ & 573050 & $16.6 \%$ & & & & & & \\
\hline Schuylkill & 845 & $0.1 \%$ & & & & & & & & \\
\hline \multirow[t]{4}{*}{ Annual Total } & 1315088 & $100.0 \%$ & 3449566 & $100.0 \%$ & 1784105 & $100.0 \%$ & 1087812 & $100.0 \%$ & 732157 & $100.0 \%$ \\
\hline & & & & & & & & & & \\
\hline & & & & & & & & & & \\
\hline & & & & 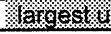 & 3hr. & & & & & \\
\hline
\end{tabular}


dispersion function; and the topographic information describing the three-dimensional coordinates of each source and receptor (population exposure grid system). For purposes of this preliminary investigation a total of five PM and five arsenic model runs were done utilizing all sources and fuel types for each of the five study years.

\subsection{Preliminary Results}

The results of each PM and each arsenic model run were converted to a citywide summary format shown in Table 3. Using the normal definition of unit risk analysis the risk at each receptor coordinate is the product of the unit risk for arsenic, the annual average arsenic concentration, and the receptor grid population (Equation 1). These summaries clearly demonstrate the effect of the shift from coal to oil in the city and the migration of coal-fired generating capacity to the suburban sites.

Table 3 also indicates the location of the maximum grid concentration and shows the "migration" of the maximum location from the Lower Northeast to West Philadelphia. This long term process follows the rise of coal as the major fuel used from 1950 through the late sixties. In the two year period 1970-1971 a significant number of coal burning boilers were removed or converted to oil. The gradual replacement of generating capacity at older city stations with nuclear power and modern coal and oil burning facilities at Cromby and Eddystone is demonstrated by this same migration pattern.

\section{$5 p R$ : RISK POWER}

In order to demonstrate the visualization simplicity of the $\mathrm{pR}$ variable the concentration and risk data summarized in Table 3 was recalculated according to Equation 3 and displayed geographically in Figures $4 a, 4 b, 4 c$, and $4 d$ for the study years 1950 through 1980 . The maximum $\mathrm{pR}$ grid location is indicated in Table 3 as the Maximum Arsenic $\mathrm{pR}$. The map for 1990 was not significantly different from 1980 and is not shown. The removal of the confounding population variable allows for a clearer view of the effect of the fuel switching and shifting of generation capacity from the older city stations to the newer suburban sites.

The communication of risk information to a wide range of individuals from the scientific community, politicians, and the general public is the most critical component of the risk assessment process. This communication process benefits from a clear visualization method for understanding the phenomenon being studied. Policymakers and individual citizens can see clearly the variation of potential health risk from power plant emissions through the "contour map" style of complex data presentation. The $\mathrm{pR}$ parameter presents data having a wide range of numerical values on a scale which is easy to comprehend. 


\section{Philadelphia Energy Risk Study}

Table 3. Annual Air Dispersion Model Receptor Results Receptor Coordinates

\begin{tabular}{|c|c|c|c|c|c|c|c|c|}
\hline$-\frac{x}{490-5}$ & $-\frac{Y}{4425} \overline{5}$ & Grid & PAS & $\frac{1950}{9}-\frac{1}{64}$ & 1960. & 1970 & 1980 & 1990 \\
\hline 490.5 & 4425.5 & 185 & G & & 24.40 & & & \\
\hline 494.5 & 4426.5 & 208 & G & & & 3.34 & & \\
\hline 477.5 & 4414.5 & 20 & C & & & & 1.22 & \\
\hline 477.5 & 4414.5 & 20 & C & & & & & 0.50 \\
\hline
\end{tabular}

Receptor Coordinates

\begin{tabular}{|c|c|c|c|c|c|c|c|c|}
\hline$-\frac{x}{490.5}$ & $-\frac{Y}{4425} \overline{5}-5$ & - Grid & PAS & $-\frac{1950}{0.000 \overline{6}}$ & 1960 & 1970 & 1980 & 1990 \\
\hline 490.5 & 4425.5 & 185 & G & & 0.0031 & & & \\
\hline 494.5 & 4426.5 & 208 & G & & & 0.0006 & & \\
\hline 477.5 & 4414.5 & 20 & C & & & & 0.0003 & \\
\hline 477.5 & 4414.5 & 20 & C & & & & & 0.0002 \\
\hline
\end{tabular}

Receptor Coordinates

Maximum Arsenic Unit Risk

\begin{tabular}{|c|c|c|c|c|c|c|c|c|}
\hline$-\frac{x}{490.5}$ & $-\frac{Y}{4425.5}$ & - Grid & PAS & $\begin{array}{l}1950 \\
0.04\end{array}$ & 1960 & 1970 & 1980 & 1990 \\
\hline 490.5 & 4425.5 & 185 & G & & 0.15 & & & \\
\hline 485.5 & 4419.5 & 92 & B & & & 0.03 & & \\
\hline 485.5 & 4421.5 & 117 & A & & & & 0.02 & \\
\hline 485.5 & 4421.5 & 117 & A & & & & & 0.01 \\
\hline \multicolumn{3}{|c|}{ City-wide Total Risk } & & 1.57 & 6.81 & 2.20 & 0.72 & 0.60 \\
\hline
\end{tabular}

Receptor Coordinates Maximum Arsenic $p R$

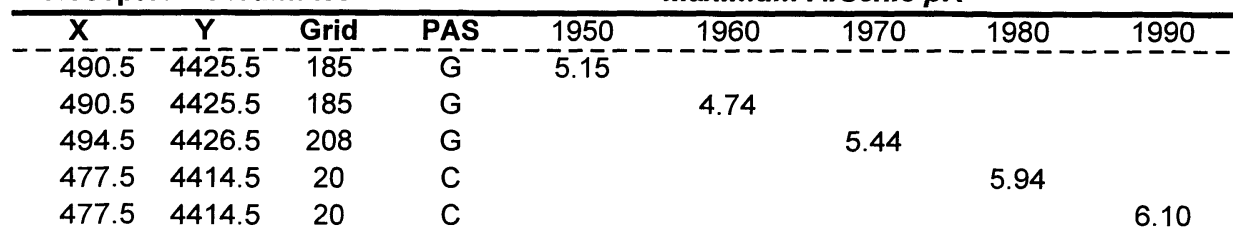

Notes: PM refers to airborne particles emitted from power plant

PAS refers to Planning Analysis Sections (see Figure 2)

Grid refers to a 1 square $\mathrm{km}$ model receptor location (see Figure 2) 
Philadelphia Energy Risk Study

Figure 4a. 1950 Airborne Arsenic Unit Risk

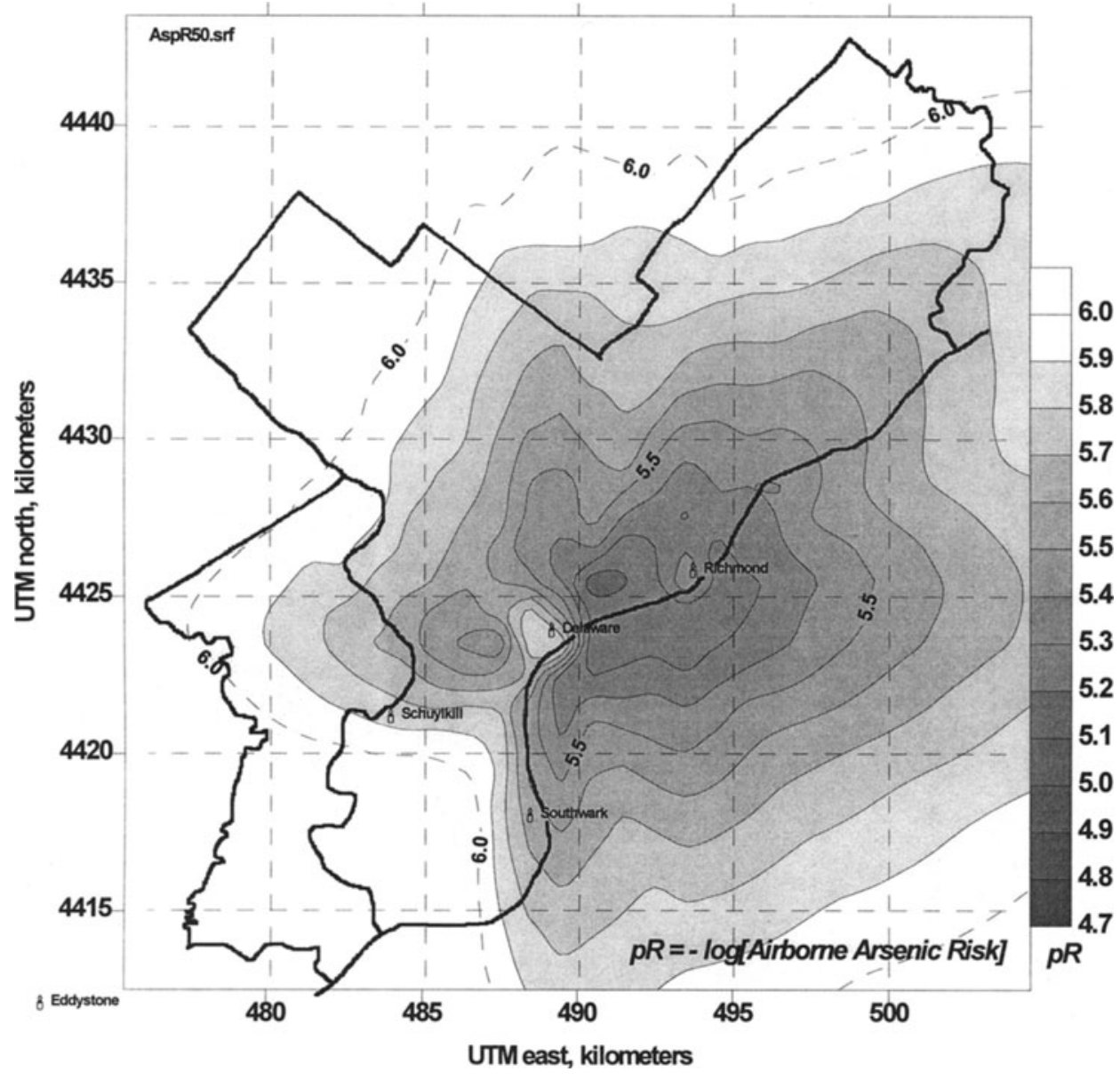


Philadelphia Energy Risk Study

Figure 4b. 1960 Airborne Arsenic Unit Risk

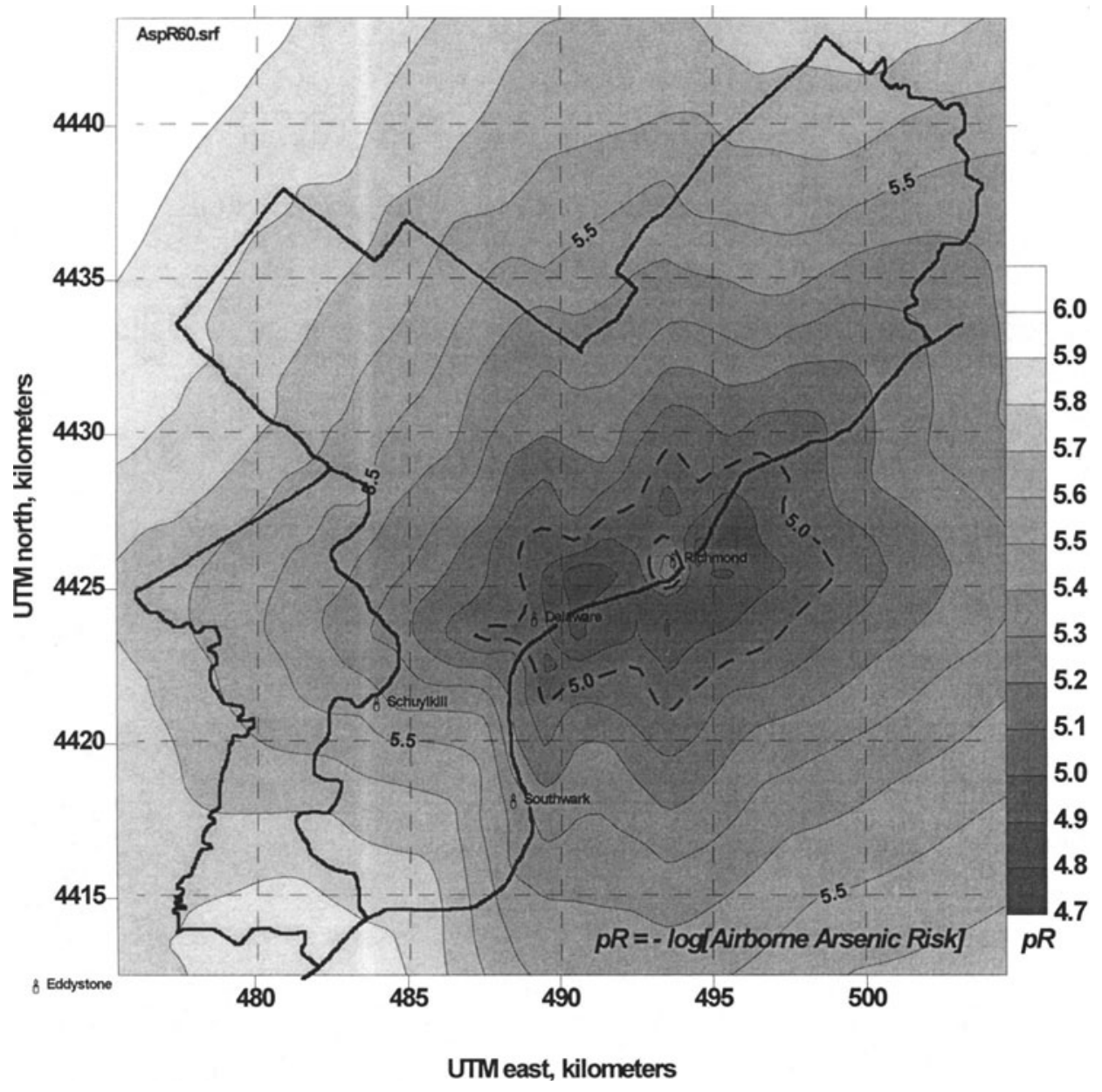


Philadelphia Energy Risk Study

Figure 4c. 1970 Airborne Arsenic Unit Risk

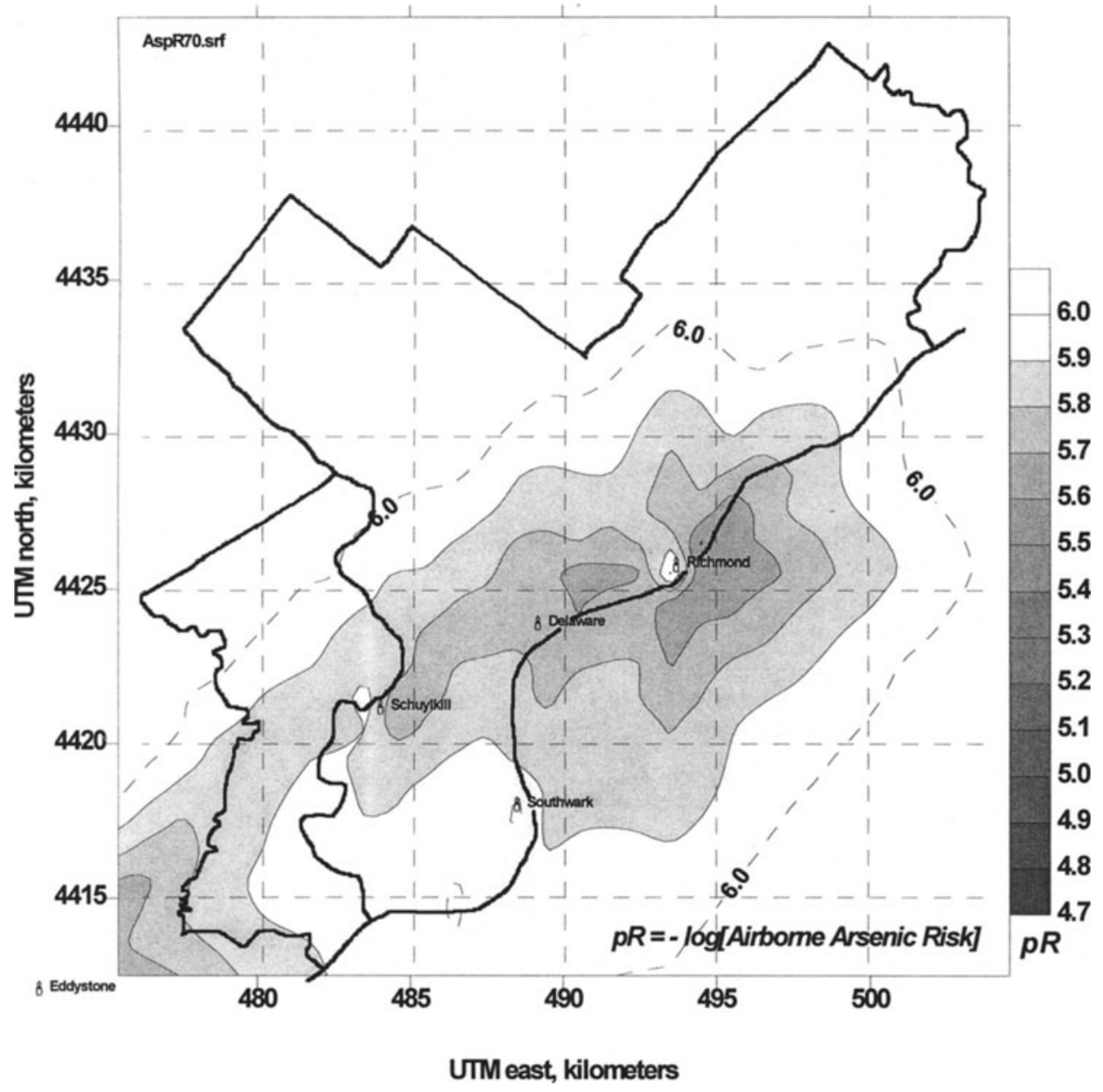




\section{Philadelphia Energy Risk Study}

Figure 4d. 1980 Airborne Arsenic Unit Risk

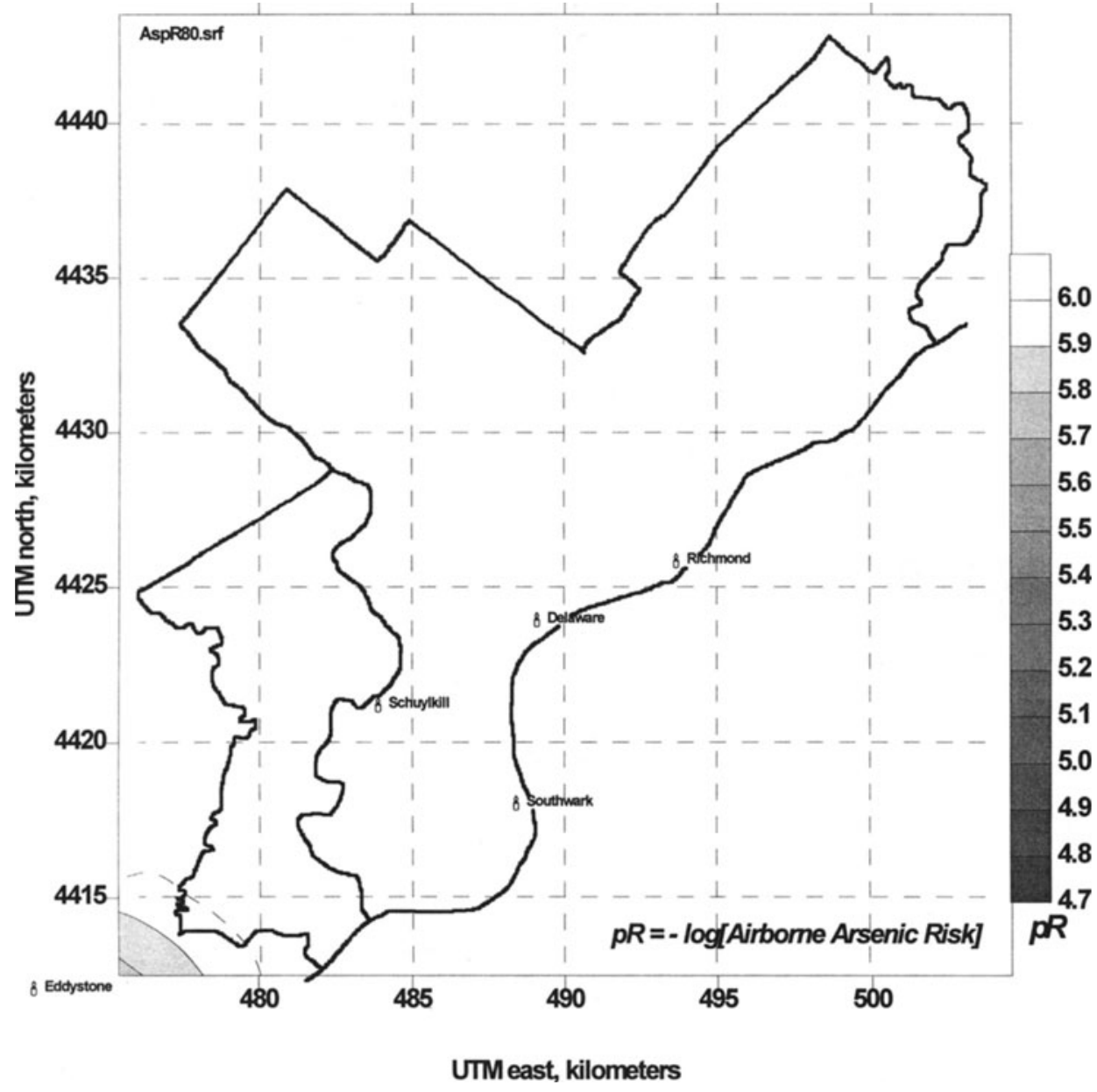




\section{REFERENCES}

Electric Power Research Institute (EPRI 1985). Assessing the Health Risk of Airborne Carcinogens, EA-4021, May 1985.

Electric Power Research Institute (EPRI 1988). Air Emissions Risk Assessment Model (AERAM) Manager: User's Guide, EA-5886-CCML, August 1988.

Feng Liu. (1994) "Environmental Risk Modeling," Report to the University of Pennsylvania, Center for Energy and the Environment, June, 1994.

Kowalczyk, G.S. et.al. (1987). "An Air Emission Risk Assessment for Benzo( $\alpha$ )pyrene and Arsenic from the Mt. Tom Power Plant," J. Air Pollution Control Association, vol. 37, pp. 361-369, 1987.

Naugle, Dennis F. and Terrence K. Pierson. (1991) "A Framework for Risk Characterization of Environmental Pollutants," J. Air \& Waste Management Association, vol. 41, no. 10, pp. 1298-1307, October 1991.

Philadelphia City Planning Commission (CPC), Census Reports for 1950, 1960, 1970, 1980, and 1990.

Philadelphia Department of Public Health, Air Management Services (AMS a), Annual Emission Inventory Report for 1970, 1980, and 1990.

Philadelphia Department of Public Health, Air Management Services (AMS $b$ ), Engineering Division, "Electric Power Generating Stations in Philadelphia," 1970.

U.S. Department of Energy (DOE 1990). Steam-Electric Plant Operation and Design Report - 1990. Energy Information Agency, Washington, D.C., 1990.

U.S. Environmental Protection Agency (EPA 1991). "Compilation of Air Pollution Emission Factors (AP-42)", Washington, D.C., 1991.

U. S. Environmental Protection Agency (EPA 1992). User's Guide for the Industrial Source Complex (ISC2) Dispersion Models; Volume II - Description of Model Algorithms, EPA-450/4-92-008b, Research Triangle Park, March 1992.

U.S. Environmental Protection Agency (EPA 1995). IRIS2 Database User's Guide, Cincinnati, Ohio, March, 1995.

U.S. Federal Power Commission (FPC 1950). Steam-Electric Plant Construction Cost and Annual Production Expenses - 1938 to 1947; Supplement 3, 1950. Washington, DC. 1950. 
U.S. Federal Power Commission (FPC 1970). Steam-Electric Plant Air and Water Quality Control Data - 1970. Washington, DC. 1970.

Wainwright, Nicholas B. (1961) History of the Philadelphia Electric Company 1881-1961. Philadelphia, Pennsylvania, 1961.

\section{Software References}

Golden Software, Inc., SURFER 5.0; Figures 4a, 4b, 4c, 4d

Hewlett Packard Company, Drawing Gallery; Figure 2

Lotus Development Corp., Ami Pro 3.0; text

Microsoft Corporation, Microsoft Excel 5.0; Figures $1 \&$ 3, Tables 1, 2, 3

\section{BIOGRAPHY}

William C. Miller is the program adviser for the Environmental Engineering graduate program at Penn State Great Valley. He is the manager for the air monitoring computer center and research programs at the Philadelphia Department of Public Health, Air Management Services Laboratory. Mr. Miller has over twenty-five years of experience in environmental engineering and related data processing systems. He holds advanced degrees in civil and environmental engineering and is a Ph.D. candidate at the University of Pennsylvania, Center for Energy and the Environment. 